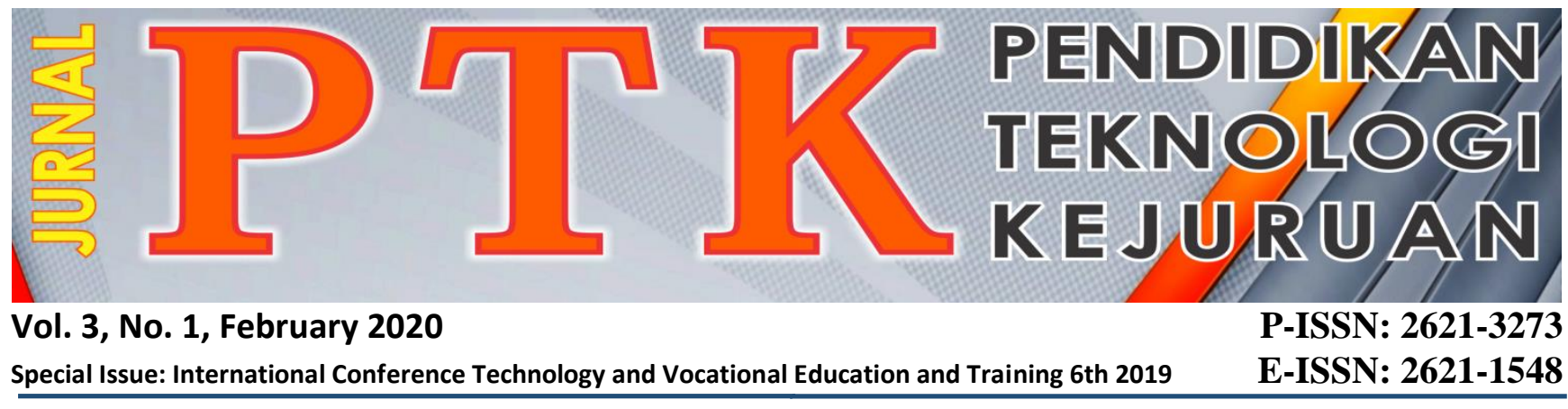

\title{
NEEDS ANALYSIS: AN INTERACTIVE E-ASSESSMENT FOR BASIC DESIGN GRAPHIC COURSE
}

\author{
Sari Azhariyah and Ambiyar \\ Faculty of Engineering, Universitas Negeri Padang \\ *Corresponding author, e-mail: $\underline{\text { s.a.az0894@gmail.com }}$
}

\begin{abstract}
This research aims to describe the results of the needs analysis in the process of developing eassessment media on the basic graphic design course. This research was a qualitative descriptive research by using survey methods in identifying the needs of students and teachers in learning assessment. In this research, the needs analysis related to the achievement of the student learning outcomes, the problems faced by the students and the media needed by students in the learning assessment process. This research used a questionnaire given to 32 students of grade $X$ and 2 teachers of the basic graphic design subject. The results showed that: 1) there was still lack of assessment media that can be used as an independent assessment for students; 2) android-based interactive assessment media was needed on the basic graphic design subject. Based on these findings, it can be concluded that students need an interactive assessment media that can be used as an independent assessment media. In addition, these findings will be used in designing interactive e-assessments in basic graphic design subject.
\end{abstract}

Keywords: Needs Analysis, E-assessment, Interactive, Android

Copyright $\odot 2020$ JPTK. All rights reserved

\section{INTRODUCTION}

The industrial revolution 4.0 is characterized by the use of technology in various aspects. One of which is smartphone technology. In education, all parts of education including teachers and students should be expected to be able to use Android technology in learning. Android is a very popular operating system because it is an open-source [1]. The use of android devices is in high demand including vocational students. Besides the price is quite affordable by the lower middle class, everyone from all ages competing to use it. This shows the possibility of using Android devices in the world of education. One form of education is vocational education.

Vocational school is a school that organizes vocational education. The learning process that occurs in the schools in the teaching process which is an activity of conveying information to students either directly by the teacher or through intermediary media, namely learning media. Another process is an evaluation that evaluates the results of the teaching process that has been given. Assessment is an ongoing process that includes planning, discussion, reflection, measurement, analysis and level of improvement based on data relating to learning objectives [2]. Student learning outcomes are known through assessment, but the function of the assessment can also monitor student progress.

One assessment is a test. The test takes the form of a series of tasks performed by one or a group of students, so as to produce the value of the student's behaviour or achievement [3]. Behaviour or achievement of students can be used as a basis for providing feedback throughout the learning process. The assessment shows the process of obtaining information, then it is used as a basis for making decisions related to the students, such as the composition of the curriculum, policies and programs that support education including the methods and instruments of education determined by certain institutions or official bodies related to education [4]. Assessment is an important part of learning activities related to student development and as feedback in improving institutional effectiveness [5]. 
Problems that occur in the field of basic graphic design subjects are assessments conducted by the teacher in a conventional way. The assessment uses paper and stationery to support the learning process. Paper that used for the assessment cannot be reused, so this method is considered a waste. In addition, greater funding is also needed in doubling the exam questions and answer sheets. The conventional assessment process has the position of students in the recipient of knowledge, this learning is measured at the lowest level of Bloom's taxonomy as knowledge and understanding [6].

The results of the analysis of observations and interviews conducted on the students of grade 10th majoring in Multimedia at SMK 4 Payakumbuh are: 1) the assessment process is still conventional with using paper and stationery so that the papers are wasted after completing the assessment; 2) the appraisal process requires more costs in multiplying questions and answer sheets; 3) the assessment process requires more time, so students needs more time to find out the results of the evaluation of learning; 4) manual appraisal has a higher probability of subjectivity in processing the valuation data; 5) the use of smartphone devices is not optimal by the teacher and students in the learning assessment process. These reasons can cause the students to be less effective and efficient in evaluating learning.

The results of the observations that cause an analysis of students' needs are important to be done. The needs analysis according to Richard \& Renandya is everything that is prioritized so it must be done in order to adjust the needs of the users [7]. Needs analysis is an initial process in developing the assessment media needed by teachers and students. E-assessment is a form of assessment using current technology. Online assessment makes the assessment process more efficient in terms of time, funding, and achievement of learning goals [8]. Online e-assessment will reduce the level of student's cheating. Students can make an independent assessment of mastery learning in accordance with learning objectives anywhere and anytime by using e-assessment. Media interactivity can affect the use of e-assessment in independent assessments conducted by students.

Needs analysis is the process of collecting systematic and ongoing data about student information, needs, and preferences, interpreting information and then making decisions based on interpretations to meet needs [9]. A fast assessment process is important because students are able to evaluate the understanding of learning in real-time based on feedback obtained previously. Media interactivity makes media more motivating for students through their interest. The use of interactive e-assessment through an android device can make the students active in evaluating. In addition, the evaluation does not have to be in the classroom. A curriculum based on improving the character and competency quality is the 2013 curriculum. Brown states that need analysis is an activity involved in gathering information so that it can serve as a basis for developing a curriculum that will meet the learning needs of certain groups of students [10].

The use of smartphone devices among vocational school students is more considered, but the use of these devices in learning has not been maximized. Students only use it as a device for communication, game, and social media. The solution to the various problems that have been outlined above is the development of interactive e-assessments as a medium assessment that can facilitate teachers in conducting assessments. It also can motivate students in evaluating learning on the Basic Graphic Design subject. One of the research is about the prospective teacher's perception of the e-assessment model in learning physics, this model has received positive responses from both teachers and students. An effective and efficient assessment process can be carried out with an e-assessment model in learning activities [11]. However, there are three types of needs that must be considered in conducting a needs analysis in research development according to Nation and Macalister [12]. The three types of needs are: 1) Need refers to skills or competencies students must have; 2) lack refers to problems or difficulties students face in learning, and 3) desire refers to reference that students need to learn in existing teaching material. The interactive e-assessment needed has a concept that combines the concept of assessment delivered through interactive electronic media as supporting media in the learning process.

\section{METHODOLOGY}

As research was an initial stage in research and development $(R \& D)$, this research was limited to the needs analysis by conducting observations. This study involved the students of grade 10th majoring in Multimedia at SMKN 4 Payakumbuh. There were 32 students who participated in giving opinions about what they needed in the assessment of basic graphic design learning. In addition, there were 2 teachers of basic graphic design subjects.

This research used a descriptive research method. Qualitative research methods are research methods based on the philosophy of positivism, which is used to examine populations or specific samples; data collection was by using research instruments, analysis of quantitative or statistical data, with the 
aim of testing established hypotheses [13]. The data were collected through survey techniques with instruments in the form of questionnaires. Questionnaires were used to find out student's opinion related to the learning assessment needs that were developed. The data obtained from the questionnaire were analyzed and then summarized in a table.

The data were obtained from the questionnaire analysis of teacher needs and student needs. The data obtained were processed in four stages: 1) collecting data from the questionnaire distribution; 2) tabulating data to see the class, nature, type, and frequency of data; 3) qualitative analysis, where the data were divided to link information related to the focus of the research and; 4) making an interpretation of the results of the problem analysis and the researcher's questions so that they can draw conclusions.

\section{RESULTS AND DISCUSSION}

The needs analysis of interactive e-assessment on basis graphic design course obtained through observation. Observations were done by 32 students from the students of grade 10th majoring in Multimedia and 2 teachers basic graphic design course in July-December 2019 semester. The research observations obtained the results presented in table 1.

Table 1. The Results of analysis of teachers' needs regarding assessment media for basic graphic design

\begin{tabular}{|c|c|c|c|}
\hline No & Question Analysis & Identification of Problems & Conclusion \\
\hline 1 & $\begin{array}{l}100 \% \text { of teachers answered that the assessment } \\
\text { process was still conventional in using paper-based } \\
\text { test }\end{array}$ & $\begin{array}{l}\text { The assessment process was still } \\
\text { conventional in the nature of using } \\
\text { paper and stationery }\end{array}$ & $\begin{array}{l}\text { Assessments that used are } \\
\text { paper-based test }\end{array}$ \\
\hline 2 & $\begin{array}{l}50 \% \text { of teachers answered that the conventional } \\
\text { assessment process caused paper waste because the } \\
\text { paper could not be used after completing the } \\
\text { assessment }\end{array}$ & $\begin{array}{l}\text { Wasting paper because paper cannot } \\
\text { be used after completing an } \\
\text { assessment }\end{array}$ & $\begin{array}{l}\text { Waste of paper in the } \\
\text { assessment }\end{array}$ \\
\hline 3 & $\begin{array}{l}50 \% \text { of teachers answered that the assessment } \\
\text { process carried out requires more costs in } \\
\text { multiplying questions and answer sheets }\end{array}$ & $\begin{array}{l}\text { It cost more to duplicate questions } \\
\text { and answer sheets }\end{array}$ & More costs in assessment \\
\hline 4 & $\begin{array}{l}100 \% \text { of teachers answered that the assessment } \\
\text { process carried out required a longer time in the } \\
\text { examination }\end{array}$ & $\begin{array}{l}\text { The assessment process carried out } \\
\text { requires a longer time in the } \\
\text { examination }\end{array}$ & $\begin{array}{l}\text { Assessment requires more } \\
\text { time }\end{array}$ \\
\hline 5 & $\begin{array}{l}50 \% \text { of teachers answered that the assessment } \\
\text { process manually had a higher chance of } \\
\text { subjectivity in processing the assessment data }\end{array}$ & $\begin{array}{l}\text { Opportunities for higher subjectivity } \\
\text { in processing assessment data }\end{array}$ & $\begin{array}{l}\text { Opportunities for higher } \\
\text { subjectivity }\end{array}$ \\
\hline 6 & $\begin{array}{l}100 \% \text { of teachers answered that there were no media } \\
\text { that supports the independent assessment that could } \\
\text { be done by students }\end{array}$ & $\begin{array}{l}\text { There were no media that supported } \\
\text { the independent assessment that } \\
\text { could be done by students }\end{array}$ & $\begin{array}{l}\text { Requires independent } \\
\text { assessment media }\end{array}$ \\
\hline 7 & $\begin{array}{l}50 \% \text { of teachers answered that it was not optimal in } \\
\text { utilizing smartphone devices in conducting } \\
\text { assessments. }\end{array}$ & $\begin{array}{l}\text { There were no media that supported } \\
\text { the independent assessment that } \\
\text { could be done by students }\end{array}$ & $\begin{array}{l}\text { The use of technology in } \\
\text { learning is not } \\
\text { maximized. }\end{array}$ \\
\hline 8 & $\begin{array}{l}100 \% \text { of teachers answered that assessment media } \\
\text { was needed so that it could improve the quality of } \\
\text { learning basic graphic design lessons. }\end{array}$ & $\begin{array}{l}\text { The quality of learning basic graphic } \\
\text { design lessons related to media } \\
\text { assessment needs to be improved }\end{array}$ & $\begin{array}{l}\text { There is a need to } \\
\text { improve the quality of the } \\
\text { assessment }\end{array}$ \\
\hline
\end{tabular}

Based on the results of the analysis of the teacher's need for interactive online-based media assessment for basic graphic design course it showed that there were no media that supported the assessment process. The assessment conducted was still a paper-based test. The teachers need to improve the quality of learning by using media as a tool in the learning process. In this case, it is in the assessment process. Interactive e-assessment is expected to be able to assist teachers in conducting the assessment. Teachers as one of the important actors in learning are expected to have the skills and creativity that bring learning to be effective, for example by selecting models, media and learning instruments [14]. This assessment did not support an independent assessment for students in real-time. Therefore, observations were done on students about the problems and expectations of the media assessment of basic graphic design lessons needed. The results of research on students in the form of data obtained were shown in table 2. 
Table 2. The Results of analysis of students' needs for assessment media on basic graphic design

$$
\text { Question Analysis }
$$

$195 \%$ of students answered that they had a smartphone and able to use it

$260 \%$ of students answered that the assessment was still conventional that required an answer paper

$378 \%$ of students answered difficulties in doing the exercise because the assessment media did not yet support the assessment that could be done by students

$485 \%$ of students answered that it took a long time to find out the results of the assessment

$588 \%$ of students want an assessment media that can be done by using current technology smartphones

$695 \%$ of students want an interactive assessment media

$794 \%$ of students want a user-friendly and mobile assessment media that they can use anytime and anywhere.

$893 \%$ of students want an assessment media that is able to present the results of the assessment directly as well as the discussion on their smartphone

The results of the analysis of students' needs showed that $73 \%$ of students had difficulties in conducting independent assessments in basic graphic design lessons. Hence, $95 \%$ of students already had and were able to use smartphone technology, and it could be used in the assessment process. Utilization of information and communication technology could be done in the assessment process as a form of evaluation of the progress of students in learning. The use of eassessment in learning is important because along with the development of technology will affect the development of the assessment process [15].

The assessment was still conventional by using a paper-based test. This form of assessment causes the assessment process carried out until the assessment results obtained require quite a long time. The assessment media desired by students was an interactive assessment media that is able to provide direct feedback in conducting assessments. The direct feedback desired by students could be in the form of assessment results and discussion of assessment questions. The learning process with eassessment based on mobile technology is more effective and efficient because it is able to attract attention and improves motivation related to the fast feedback obtained [16]. This assessment media was in the form of assessment media using technology such as smartphones and can be accessed online. Online assessment media will connect directly between students and teachers in accessing assessment results. Assessment is considered as part of the learning process that provides ongoing feedback for students and educational institutions [17]. This is needed to develop interactive eassessments that can be accessed online using smartphones for basic graphic design lessons based on needs analysis. This needs analysis showed $100 \%$ needs of teachers in improving the quality of learning media and $94 \%$ of students of needs for media assessments were mobile, interactive and support independent assessment in real-time.

\section{IV.CONCLUSION}

This research aims to describe the results of the needs analysis in the process of developing eassessment media on a basic graphic design course. Based on the results and discussion of this research, it shows that the development of interactive eassessment is needed. The needs analysis shows that there are $100 \%$ of teachers that need to improve the quality of assessment and learning assessment media. In addition, 94\% of students need an assessment media that is interactive, mobile and utilizes technology so that they can make an independent assessment in evaluating understanding of learning. Therefore, there is a need to develop interactive e-assessments that support student self-assessment, interactive-based and can improve the quality of assessments conducted by teachers.

\section{REFERENCE}

[1] Safaat H, Nazaruddin. Pemrograman Aplikasi Smartphone dan Tablet PC berbasis Android (Bandung: Informatika) p 1. 2012.

[2] Martell, K., \& Calderon, T. Assessment of student learning in business schools: What it is, where we are, and where we need to go next. In K. Martell \& T. Calderon, Assessment of student learning in business schools: Best practices each step of the way Tallahassee (vol 1) (Florida: Association for Institutional Research) chapter 1 pp 1-22. 2005.

[3] Ambiyar. Pengukuran dan Tes dalam Pendidikan (Padang : UNP Press). 2012.

[4] Anthony J Nitko. Educational Assessment Of Students (New Jersey/Columbus: Ohio, Merril, an Imprint of Prentice Hall) p 4. 1996. 
[5] Hersh R. Assessment and accountability: Unveiling value added assessment in higher education A Presentation to the AAHE National Assessment Conference (Denver: Colorado). 2004.

[6] Robles $M$ and Braathen S. Online Assessment Techniques Delta Pi Epsilon Journal (vol 44) chapter 1 pp 39-49. 2002.

[7] J.C. Richards and W.A. Renandya Methodology in Language Teaching: An Antology of Current Practice (Cambridge: Cambridge University Press). 2003.

[8] Sorensen E. Implementation and student perceptions of e-assessment in a Chemical Engineering Module European Journal of Engineering Education (vol 38) chapter $2 \mathrm{pp}$ 172-185. 2013.

[9] K. Graves. Teachers as Course Developers (New York: Cambridge University Press). 1996.

[10] J.D. Brown. The Element of Language Curriculum: A Systematic Approach to Program Development (Boston: Henle \& Heinle Publisher) 1995.

[11] Hairunisyah Sahidu and Gunawan and Indriaturrahmi, and Fitri Astutik. Desain Sistem E-assessment dalam Pembelajaran Fisika di LPTK Journal of Physics and Technology Education (vol 3) chapter 2 pp 265-270. 2017.

[12] I.S.P. Nation and J. Macalister. Language Curriculum Design (New York: Routledge) 2010.

[13] Sugiyono. Metode Penelitian Kuantitatif Kualitatif dan R\&D (Bandung: Alfabeta). 2016.

[14] Suranti N M Y and Gunawa G and Sahidu H. The Effect of Project Based Learning Model Assisted with Virtual Media on the Mastery of Student Concepts on Material Optical Devices Journal of Physics and Technology Education (vol 2) chapter 2 pp 73-79. 2016.

[15] Andrew Boyle and Dougal Hutchison. Sophisticated Task In E-Assessment: What Are They And What Are Their Benefit? Assessment \& Evaluation in Higher Education (vol 34) chapter 3 pp 305-319. 2009.

[16] Anggara Rikko. Pengembangan EAssessment Berbasis Teknologi Mobile dalam Program Aplikasi Komputer di Departemen Teknologi Pendidikan State University of Malang Thesis State University of Malang. 2013.
[17] Nicole A Buzzetto-More and Ayodele Julius Alade. Best Practices in e-Assessment Journal of Information Technology Education (vol 5) chapter 1 pp 251-269. 2006.

[18] S. Syahril, N. Jalinus, R. A. Nabawi, and Y. Arbi, "The Create Skills of Vocational Students to Design a Product: Comparison Project Based Learning Versus Cooperative Learning-Project Based Learning," Adv. Soc. Sci. Educ. Humanit. Res., vol. 299, no. 5th UPI International Conference on Technical and Vocational Education and Training (ICTVET 2018) The, pp. 316-320, 2019. 